\title{
Psychological Linguodidactics of Speech Development Activity of Senior School Age Children with Autistic Abnormalities
}

\section{Психолінгводидактика розвитку мовленнєвої активності дітей старшого дошкільного віку з аутистичними порушеннями}

Daria Suprun

Dr. in Pedagogy, Professor
Дар'я Супрун

доктор педагогічних наук, професор

\section{E-mail: darya7@ukr.net orcid.org/ 0000-0003-4725-094X}

Maryna Fedorenko

Ph.D. in Psychology,

Senior Lecturer

\section{Марина Федоренко}

кандидат психологічних наук, старший викладач

E-mail: mv fedorenko@i.ua orcid.org/ 0000-0002-2421-3049

National Pedagogical

Dragomanov University,

Department of Special

Psychology and Medicine

9, Pyrogova Str., Kyev,

Ukraine, 01601
Національний

педагогічний університет імені М.П. Драгоманова, кафедра спеціальної психології та медицини

$\checkmark$ вул. Пирогова, 9, м. Київ,

Україна, 01601

Original manuscript received September 27, 2018

Revised manuscript accepted March 02, 2019

\section{ABSTRACT}

Children of senior preschool age with autistic problems have a predominantly low level of speech activity, therefore, the aim of the article is to theoretically substantiate 
and develop a phased correctional developmental psycholinguodidactic technology of forming speech activity of children determined age by using theoretical (study, analysis and generalization of the theoretical and methodological foundations of the research for determining the state of development of the problem and perspective directions of its study) and empirical (psychological and pedagogical experiment to study the state and features of the development of speech activity of children of senior preschool age with autistic disorders) research methods.

The experimental psycholinguodidactic technology contained three stages of work on the problem of speech activity: research-diagnostic, correctional-activity and functional-speech.

The emotional contact was established and improved, and the initial level of speech activity was diagnosed at the research-diagnostic stage. Correctional-activity stage consisted in the formation of speech and communication skills, the development of direct speech activity of children of senior preschool age with autistic disorders. The diagnosis and consolidation of the child's achievements regarding speech activity was provided at the functional-speech stage, as well as the ability to use the acquired speech skills in the process of communication, filling the process of communication with broad interrelations with the environment.

The results of the formative experiment confirmed that although children of senior preschool age with autistic disorders did not reach a high level of speech activity, but in the experimental group there were identified children with a sufficient level, the number of children with an average level increased, and the number of children with zero level of speech activity decreased, which confirms the effectiveness of experimental psycholinguodidactic correctional technology.

Key words: psycholinguodidactic correctional technology, autistic disorders, senior preschool age, speech activities, speech activity, correctional-developing technique.

\section{Вступ}

Актуальність проблеми зумовлена концептуальними засадами реформування системи освіти в Україні, спрямованими на формування життєвої компетентності дітей з особливими освітніми потребами, як зазначено в «Державному стандарті початкової загальної освіти для дітей з особливими освітніми потребами» та «Державному стандарті початкової освіти».

Мова та мовлення завжди були в центрі особливої уваги лінгвістів, психологів, психолінгвістів, логопедів, медиків, клініцистів (Ахутина, 1989; Белянин, 2009; Визель, 2005; Жинкин, 1998; Зимняя, 2000; Калмикова, 2011; Леонтьев, 2005; Шульженко \& Шеремет, 2013 та ін.). 
Psychological Linguodidactics of Speech Development Activity...

Оволодіння мислемовленням - складний, багатосторонній нейропсихічний i психовербальний процес. Зауважимо, що саме стан сформованості мовлення на кінець дошкільного віку $\epsilon$ важливим показником перспектив подальшого сприятливого розвитку. Показово, що діти, які не оволоділи мовленням до 5-и років і які демонстрували низькі інтелектуальні можливості, важче адаптуються до соціальної ситуації розвитку.

Різні питання, що стосуються розвитку та порушень мовлення в дітей дошкільного віку, вивчалися як зарубіжними, так вітчизняними вченими, зокрема: психологія розвитку мовленнєвої діяльності дітей дошкільного віку (Калмикова, 2011); розрізнення дошкільниками іменників та дієслів (Barbosa \& Nicoladis, 2016); роль вербальної пам'яті в усвідомленні речення дошкільниками (Boyle, Lindell \& Kidd, 2013); використання просодії в розумінні речення дітьми 3-4 років (Choi \& Mazuka, 2003); вплив мовлення на розвиток дитини (Foursha-Stevenson et al., 2017); синтаксична сторона мовлення дошкільників (Hurewitz et al., 2009) тощо.

Проблемами мовленнєвого розвитку дітей 3 аутистичними порушеннями займалися вчені різних галузей наук (Баенская, 2001; Базима, 2013; Башина, 1999; Конопляста \& Косинкіна 2013; Лебединская \& Никольская, 1991; Морозова, 2007; Никольская, Баенская \& Либинг, 2000; Никольская et. al., 2005; Рождественська \& Конопляста, 2004; Тарасун, 2014; Шульженко, 2009; Шульженко \& Шеремет, 2013 та ін.). Вони відзначили порушення комунікативної функції мовлення в цієї категорії дітей, що проявляється як у нездатності повноцінно сприймати вербальну інформацію, так і в неможливості створювати адекватне мовленнєве висловлювання та доречно взаємодіяти відповідно до конкретної життєвої ситуації.

$\mathrm{У}$ той же час у дітей $з$ аутистичними проявами порушується формування усіх форм довербального й вербального спілкування. I чим старшою стає дитина, тим більш виражено проявляються в неї труднощі при взаємодії іiі з оточуючими людьми та з навколишнім середовищем (Баенская 2001; Базима, 2013; Башина, 1999; Богдашина, 1999; Лебединская \& Никольская, 1991; Никольская, Баенская \& Либинг, 2000; Никольская еt. al., 2005; Островська, 2012; Скрипник, 2010; Тарасун, 2014; Шульженко, 2009; Шульженко \& Шеремет, 2013 та ін.). 
Серед найхарактерніших порушень мовленнєвого розвитку при аутизмі вчені виділили наступні: а) мутизм; б) автономність мовлення; в) фотографічність мовлення, що часто при хорошій пам'яті створює ілюзію розвинутого мовлення; г) широке використання неологізмів; г) ехолалії, часто відірвані в часі; д) слова-штампи, фрази-штампи; е) відсутність звертання; є) нездатність до ведення діалогу; ж) недостатність монологічного мовлення; 3) пізня поява в індивідуальному мовленні особових займенників і їх неправильне використання; и) відсутність слів «так» i «ні»; i) помилки семантико-змістового рівня мовлення; i) нездатність до словотворчості; й) порушення синтаксичної структури речення; к) порушення граматичної будови словосполучень; л) помилкова звуковимова; м) ненормативна мелодика вимови; н) відхилення в ритміко-інтонаційних особливостях просодичних компонентів мовлення.

Слід підкреслити неоднорідність мовленнєвих помилок i варіативність їх проявів у залежності від глибини ураження та ступеню викривлення психічного розвитку дитини. Та при аутизмі, незалежно від рівня розвитку мовлення, насамперед, страждає можливість активно використовувати його 3 метою якісного й повноцінного спілкування для взаємодії з однолітками й дорослими.

Мовленнєва активність дітей старшого дошкільного віку $є$ однією 3 численних форм загальної активності, відображенням потреб дитини, що виникають відповідно до конкретних ситуацій спілкування.

О. Леонтьєв виділив п'ять послідовних, взаємопов'язаних етапів (фаз) мовленнєвої активності (Леонтьев, 2005): а) мотив висловлювання; б) задум його; в) внутрішне програмування; г) лексично-граматичне розгортання висловлювання; г) реалізація мовленнєвого висловлювання у зовнішній комунікації. Зрозуміло,як свідчить практика, що в дітей 3 аутистичними відхиленнями на кожному із виділених О. Леонтьєвим етапів, покладених у структуру мовленнєвої діяльності, виникають ті чи інші затруднення, пов'язані 3 особливостями індивідуального комунікативного та мовленнєвого розвитку особистості дитини.

Розуміючи важливість якісної діагностики, зазначимо, що попри те, що дошкільний вік - це період найбільш виражених класичних проявів дитячого аутизму, зокрема, в мовленнєвому 
розвитку, за умови своєчасно розпочатої психолінгвокорекційної роботи можна досягти позитивних зрушень, як у поліпшенні якості усного мовлення, так i в розвитку психічних процесів i функцій, що стануть запорукою більш швидкої адаптації та соціалізації дітей 3 особливими потребами. Поява активного мовлення в дитини значною мірою залежить від своєчасності переходу iї на новий рівень співробітництва 3 дорослими. Тому виникає необхідність стимулювання пріоритетів дитини, зокрема, 3 аутистичними відхиленнями, в спілкуванні з дорослими, а також у створенні спеціальних умов для цього, спрямованих на активізацію мовленнєвого розвитку дошкільника.

Як показав теоретичний аналіз, діти старшого дошкільного віку з аутистичними проблемами мають переважно низький рівень мовленнєвої активності, тому в статті поставили за мету теоретично обгрунтувати й розробити поетапну корекційно-розвивальну психолінгводидактичну технологію формування мовленнєвої активності дітей старшого шкільного віку.

\section{Методи та методики дослідження}

У процесі обстеження використовувалися такі методи, як: аналіз, систематизація, узагальнення даних загальної та спеціальної психології, психолінгвістики розвитку, та патопсихолінгвістичної літератури $з$ проблеми дослідження. Це дало достатню наукову основу для: а) встановлення теоретико-методичних засад і основних підходів до 3'ясування сутності мовленнєвого розвитку дітей 3 аутистичними порушеннями, конкретизації основних компонентів i показників; б) спостереження за навчально-розвивальним процесом, проведення бесід, опитування вихователів, збір та критичний аналіз анамнестичних даних 3 метою визначення стратегії експериментального дослідження; в) формувальний та контрольний експерименти для визначення рівнів мовленнєвої активності в старших дошкільників 3 аутистичними відхиленнями від загальної норми; г) кількісна та якісна обробка одержаних результатів дослідження, статистичне обрахування за критерієм Фішера для оцінки достовірності відмінностей між відсотковими частками вибірок щодо сформованості мовленнєвої активності в дітей 3 аутистичними порушеннями. 
Експериментальна психолінгводидактична (корекційнорозвивальна) технологія містила три етапи роботи над проблемою мовленнєвої активності: дослідницько-діагностичний, корекційнодіяльнісний та функціонально-мовленнєвий.

Мета дослідницько-діагностичного етапу полягала у встановленні й налагодженні емоційного контакту, а також у діагностиці наявного вихідного рівня мовленнєвої активності. У зв'язку 3 цим змістом роботи на даному етапі визначені: діагностика рівнів мовленнєвої активності; психолінгвістичні технології формування доступних навичок спілкування (вербальних і невербальних); виявлено афективно значимі стимули для дитини, здійснений пошук відправної точки для побудови контакту 3 нею; налагоджено контакт 3 дитиною 3 метою формування в неї мотивації до взаємодії з дорослими; забезпечено розвиток здатності до наслідування й корекцію слухової уваги; розширено й уточнено пасивний словник й виявлено провідні та розвинуто доступні навички спілкування.

Для з'ясування вихідного рівня розвитку мовленнєвої активності в старших дошкільників 3 аутистичними порушеннями було застосовано наступні психолінгводіагностичні технології: спостереження над мовленням дітей; обстеження та визначення рівнів мовленнєвої активності дітей $з$ аутистичними проблемами (Шульженко, 2009), що включало вивчення таких компонентів, як умотивованість, ініціативність і змістовність мовленнєвої активності; вивчення особових справ дітей; опитування (батьків, логопедів, вихователів, дефектологів, психологів).

Оскільки діти 3 аутистичними порушеннями, зазвичай, відчувають затруднення в наслідуванні як загальному, так i безпосередньо мовленнєвому, пропонується підвищити дану здатність за допомогою відповідних ігор. Крім того, для становлення й закріплення безпосередньо мовленнєвого наслідування вважаємо за необхідне поєднувати розвиток координації між мовленнєвою й руховою сферами поряд з розвитком слухової уваги, формуванням умінь відтворювати зміст літературних творів, використовуючи вигуки чи звуконаслідування й різні рухи. Даний етап роботи також включав діагностику й розвиток імпресивного та експресивного словника, представленого різними частинами мови. 
Мета корекиійно-діяльнісного етапу полягала у формуванні мовленнєвих та комунікативних умінь, розвитку безпосередньо мовленнєвої активності в дітей старшого дошкільного віку 3 аутистичними порушеннями. Зміст роботи на даному етапі включав: підвищення мотивації до взаємодії та спілкування; розвиток ініціативності дитини в процесі спілкування на фоні активного контакту 3 оточуючими людьми; перехід від наявних навичок спілкування до більш повного використання мовленнєвих засобів: розширення пасивного й активного словникового запасу; формування основ граматичної побудови словосполучення; розвиток у дітей старшого дошкільного віку практичних умінь відповідати на запитання; формування первинних навиків правильно будувати фрази.

Для розвитку мотивації до взаємодії 3 дорослими та ініціативності в спілкуванні застосовувалися психолінгводидактичні технології заохочення (сенсорні, активні, соціальні) 3 перспективою переходу до переважного використання соціальних заохочень (похвали та соціальних знаків). Крім того, змістом і наповненням ігор передбачалася варіативність залежно від уподобань та інтересів дитини, що також підвищувало мотивацію до взаємодії з дорослим для отримання задоволення - спочатку від взаємодії з іграшками чи предметами, яку організовував дорослий, а потім - безпосередньо від взаємодії з дорослим.

Кожне заняття й кожна гра або вправа в межах одного заняття проводилися емоційно, що, з одного боку, мотивувало дитину до взаємодії, а з іншого - стимулювало виникнення ініціативності в спробах ініціювати під час спілкування 3 дорослим саме той вид діяльності, який був би найбільш актуальним, цікавим і бажаним для дитини. Для вироблення й закріплення навиків самостійності, ініціативності та вмотивованості до взаємодії 3 іншими людьми організовувалися ігри, що сприяли самоідентифікації дитини.

Багаторазове повторення одних і тих самих ігор 3 різним сюжетно-смисловим наповненням, використання якого, крім забезпечення психолінгводидактичної мети, базувалося на врахуванні особливостей дітей 3 аутистичними порушеннями (прагнення до одного й того самого порядку, стереотипність, нетерпимість до нововведень і змін та ін.) сприяло не лише розширенню пасивного 
словника, але й давало змогу відпрацьовувати одні й ті самі мислемовленнєві дії.

Перехід від доступних дитині навичок спілкування до більш широкого використання наявних у літературній мові мовленнєвих засобів забезпечувався інструкціями типу «Назви», «Скажи», «Подумай», «Заміни» та запитаннями типу «Хто це?», «Який?», «Яка?», «Як?», «Де?», «Коли?», «Куди?», «Чому?» і т.п. У випадках, коли дитина не відповідала, дорослий, витримавши паузу, відповідав замість неї. Якщо дошкільник робив хоча б мінімальну спробу самостійно дати вербальну відповідь або відтворити іiі за дорослим (навіть за невдалих спроб), то це обов'язково стимулювалося похвалою та відповідним заохоченням, що підтримувало вербальноінтелектуальні зусилля дитини до взаємодії. Прикладом можуть бути ігри типу «Покажи і назви», «Назви частину тіла» та ін.

Метою функціонально-мовленнєвого етапу - діагностика й закріплення досягнень дитини відносно мовленнєвої активності, а також уміння користуватися набутими мовленнєвими навиками в процесі комунікації, наповнення процесу спілкування широкими взаємозв'язками 3 оточенням. Зміст функціонально-мовленнєвого етапу корекційно-розвивальної роботи передбачав: а) діагностику рівня сформованості мовленнєвої активності; б) подальше розширення й поповнення словникового запасу (як пасивного, так i активного); в) удосконалення граматичної будови словосполучень і речень; г) психолінгвоментальний розвиток діалогічного мовлення дошкільників (уміння відповідати на запитання); г) вироблення й закріплення здатності до фразового монологічного висловлювання; д) стимулювання й активізація в дітей старшого дошкільного віку ініціативності та активності в спілкуванні.

На цьому етапі найбільше виявляються ознаки особистісно орієнтованої моделі освіти у формуванні мовленнєвої активності в дітей з аутистичними порушеннями старшого дошкільного віку, що забезпечує цілісне становлення особистості дитини, пї мовленнєвої й комунікативної компетентності.

Формуванням мовленнєвої активності в дітей цієї категорії на даному етапі досягалося практичне ознайомлення з граматичними формами слів рідної мови (морфологічний склад - частини мови) і засвоєння основних способів словотвору; розвиток граматичного чуття рідної мови та стійких асоціативних зв'язків. 
Psychological Linguodidactics of Speech Development Activity...

Передбачалося включення деяких ігор попередніх етапів, але, якщо на попередніх етапах допускалося просто відтворення рухів відповідно до ігрової ситуації або проговорювання окремих слів чи фраз, то даний етап передбачав відтворення безпосередньо віршованого тексту гри.

Варто зазначити, що, враховуючи особливості психічного розвитку дітей з аутистичними порушеннями, допускалося тимчасове повернення до використання прийомів і засобів попереднього етапу у випадках зниження показників мовленнєвої активності. Крім того, активно використовувалися короткі, чіткі, зрозумілі коментарі стосовно усього, що відбувалося $з$ дитиною та навколо неї в момент взаємодії. Метою таких коментарів були спроби поліпшувати орієнтування дитини в навколишньому просторі, формувати зв'язки між об'єктами, діями та їх вербальними відповідниками, повідомляти про комунікативну присутність співрозмовника, а також сприяти активації мовленнєвої активності.

Експериментом було охоплено 61 дитину 3 аутистичними порушеннями старшого дошкільного віку. Для забезпечення ефективності впровадження розробленої психолінгводидактичної технології було сформовано експериментальну (ЕГ) та контрольну (КГ) групи. До експериментальної групи залучено 32 дитини, яким було запропоновано серію завдань 3 корекційно-розвивальної психолінгводидактики для формування мовленнєвої активності. До контрольної групи увійшло 29 дітей, які не були охоплені спеціальним навчанням, але брали участь у прикінцевому функціонально-мовленнєвому етапі формувального експерименту.

Залучаючи дітей 3 аутистичними порушеннями до експериментального дослідження, ми не проводили відбір за певними показниками (скажімо, рівень мовленнєвої активності чи мовленнєвого досвіду, рівень інтелектуального розвитку, контактнісгь тощо), а орієнтувалися лише на згоду батьків. Таким чином, на початковому етапі формувального дослідження експериментом були охоплені діти старшого дошкільного віку 3 різним рівнем мовленнєвої активності.

Корекційно-розвивальні занятя за запропонованою психолінгвістичною технологією проводилися в індивідуальній формі, що пояснюється різними мовленнєвими можливостями 
дітей та характерними аутистичними особливостями. Корекційнорозвивальною технологією формування мовленнєвої активності враховувалися програмові вимоги розвитку дитини старшого дошкільного віку та принципи організації корекційної роботи 3 дітьми цієї категорії. Поліпшення рівня сформованості мовленнєвої активності розглядалося як динамічний процес, що характеризувався певними особливостями в залежності від механізму виникнення мовленнєвого порушення й грунтувався на закономірностях онтогенетичного розвитку мовлення. Крім того, враховувалися індивідуальні можливості мотиваційно-вольової сфери та стану розвитку мовлення дитини з аутистичними порушеннями старшого дошкільного віку.

У процесі роботи відбувалися початкове й заключне оцінювання умінь і навичок дитини, організація занять переважно індивідуальної форми у звичних для дітей умовах, у дружній позитивній атмосфері, спираючись на ігровий момент пред'явлення й виконання завдань, що забезпечувало значну ефективність застосування принципу індивідуального й диференційованого підходу 3 урахуванням інтелектуальних можливостей дітей, особливостей їх емоційно-вольової сфери, а також комунікативних проявів, ступеню тяжкості дефекту, що вимагає надання різного рівня допомоги.

Контрольні зрізи 3 метою виявлення ефективності експериментальної психолінгвістичної технології формування мовленнєвої активності у старших дошкільників 3 аутистичними порушеннями проводилися на прикінцевому етапі.

Розробленою експериментальною технологією формування мовленнєвої активності свідомо передбачалося декілька рівнів допомоги: а) пояснення процесу виконання завдання на декількох схожих зразках 3 активним використанням наочного матеріалу; б) показ зразка дії або відповіді на схожому матеріалі 3 метою розвитку навичок відповіді за аналогією; в) вибір дії або відповіді 3 2-3 варіантів; г) показ зразка дії або відповіді для репродуктивного відтворення; г) дія за наслідуванням або відображувальне промовляння відповіді; д) виконання завдання замість дитини зі спонуканням іiі до взаємодії. 


\section{Результати та дискусії}

Для перевірки ефективності експериментальної психолінгвістичної методики було використано ту саму методику, що й на дослідницько-діагностичному етапі. Розглянемо отримані показники сформованості мовленнєвої активності в старших дошкільників контрольної та експериментальної груп до і після реалізації завдань формувального етапу експериментального дослідження (табл. 1).

Таблиця 1. Розподіл дітей старшого дошкільного віку експериментальної та контрольної груп до і після експериментального дослідження за рівнем сформованості мовленнєвої активності (у \%)

\begin{tabular}{|c|c|c|c|c|c|c|}
\hline \multirow{2}{*}{$\begin{array}{l}\text { Рівні сформованості } \\
\text { мовленнсвої } \\
\text { активності }\end{array}$} & \multicolumn{2}{|c|}{$\begin{array}{c}\text { На початку } \\
\text { експерименту }\end{array}$} & \multicolumn{2}{|c|}{$\begin{array}{c}\text { Після } \\
\text { експерименту }\end{array}$} & \multicolumn{2}{|c|}{$\varphi^{*}$} \\
\hline & $\mathbf{E \Gamma}$ & КГ & $\mathbf{E \Gamma}$ & КГ & $\mathbf{E \Gamma}$ & КГ \\
\hline Високий & 0 & 0 & 0 & 0 & - & - \\
\hline Достатній & 3,6 & 3,4 & 13,5 & 6,3 & 2,28 & 0,70 \\
\hline Середній & 10,9 & 12,6 & 20,3 & 16,7 & 1,48 & 0,59 \\
\hline Низький & 26,6 & 25,4 & 27,6 & 28,2 & 0,11 & 0,32 \\
\hline Нульовий & 58,9 & 58,6 & 38,6 & 48,8 & 2,28 & 1,02 \\
\hline
\end{tabular}

Для визначення ступеня статистичної відмінності між реципієнтами був використаний багатофункціональний критерій $\varphi^{*}$ Фішера (кутове перетворення Фішера), який дав можливість оцінити достовірність відмінностей між відсотковими частинами визначеного показника у двох вибірках.

Для співставлення вибірок за кількісно виміряною ознакою скористалися багатофункціональним критерієм $\varphi^{*}$ Фішера, що обчислюється за формулою:

$$
\varphi^{*}=\left(\varphi_{1}-\varphi_{2}\right) \times \sqrt{ } \quad \begin{gathered}
\mathrm{n}_{1} \cdot \mathrm{n}_{2} \\
\mathrm{n}_{1}+\mathrm{n}_{2}
\end{gathered} ;
$$

де $\varphi_{1}-$ кут, який відповідає більшому \% показника; $\varphi_{2}$ - кут, що відповідає меншому \% показника; $\mathrm{n}_{1}$ - кількість спостережень у вибірці $1 ; \mathrm{n}_{2}$ - кількість спостережень у вибірці 2.

Обчислення за критерієм Фішера показало, що позитивна динаміка характерна лише для експериментальної групи, адже 
для достатнього рівня мовленнєвої активності показник $\varphi^{*}=2,28$ в ЕГ, а в КГ він $є$ несуттєвим i $\varphi^{*}=0,70$. Тобто результати експерименту підтвердили доцільність впровадження розробленої психолінгводидактичної технології й проведеної корекційнорозвивальної роботи з формування мовленнєвої активності старших дошкільників 3 аутистичними порушеннями.

Високого рівня мовленнєвої активності не досягла жодна дитина. Це пояснюється тим, що діти 3 аутизмом - це досить неоднорідна група, яка об'єднує дітей з різними аутистичними особливостями, що впливають на психічний розвиток i комунікативно-мовленнєву функцію. Але в результаті проведеного формувального дослідження суттєво збільшилася кількість дошкільників ЕГ, які знаходилися на достатньому та середньому рівнях мовленнєвої активності (майже на 10\%). Кількість дітей на низькому рівні залишилася майже незмінною. Більше ніж на 20\% зменшилася кількість дошкільників, які знаходилися на нульовому рівні мовленнєвої активності.

Діти, які після проведення формувального дослідження знаходилися на достатньому рівні (ЕГ - 13,5\%, КГ - 6,3\%), були здатні вступати в контакт 3 дорослим, але вибірково, за умови відповідної мотивації виконували їх прохання. Вони приймали допомогу, свої бажання виражали як вербально, так і не вербально (частіше). У мовленні діти цієї категорії використовували переважно непоширені речення або фрази; кількість ехолалій і мовленнєвих штампів була мінімальною. Вони були здатні до монологічного висловлювання та до ведення діалогу 3 ініціативи дорослого на цікаві й доступні теми.

Дошкільники 3 середнім рівнем розвитку мовленнєвої активності (ЕГ - 20,3\%, КГ - 16,7\%) здатні були вибірково вступати в контакт 3 дорослим, але взаємодія не завжди була успішною. Свої бажання виражали не вербально, в мовленні спостерігалося переважне використання фраз, слів, словосполучень, були присутні ехолалії та мовленнєві штампи, займенник «Я» переважно відсутній.

Діти 3 низьким рівнем мовленнєвої активності (ЕГ - 27,6\%, КГ - 28,2\%) майже ніколи не вступали в контакт з власної ініціативи, усі прохання ними виконувалися лише за умови підвищеної мотивації. Вони, фактично, не здатні до діяльності під керівництвом 
Psychological Linguodidactics of Speech Development Activity...

дорослого. У мовленні цих дітей спостерігаються звуконаслідування, звукокомплекси, вокалізації, ехолалії, мовленнєві штампи.

Значний відсоток (ЕГ - 38,6\%, КГ - 48,8\%) склали дошкільники 3 нульовим рівнем мовленнєвої активності. Вони не проявляли активності, не реагували на дорослих, не виявляли інтересу до взаємодії, не сприймали допомогу дорослого, взагалі не використовували слова. У них спостерігалася нездатність до монологічного мовлення та до ведення діалогу.

Отже, результати психолінгводидактичного впливу засвідчили, що за умови спеціально організованої, цілеспрямованої, послідовної та систематичної корекційно-розвивальної роботи 3 дітьми старшого дошкільного віку, які мають аутистичні порушення, підвищується рівень їх мовленнєвої активності, хоча респонденти й не досягли високого рівня іï розвитку. Але всі дошкільники 3 аутистичними порушеннями потребують ранньої та систематичної корекційної психолінгводидактичної роботи для підготовки їх до навчання, до оволодіння елементарними формами комунікації та взаємодії 3 оточуючими людьми.

\section{Висновки}

Проаналізувавши загальну й спеціальну психолінгвістичну літературу та узагальнивши дані, отримані під час проведення психолінгводидактичної роботи й безпосереднього спостереження над мовленням i мовою дітей старшого дошкільного віку 3 аутистичними порушеннями, було визначено умови корекційного підходу до розвитку мовленнєвої активності дітей зазначеної категорії, а саме: а) спостереження за дитиною та безпосередня взаємодія 3 нею й об'єктивна оцінка динаміки розвитку мовленнєвої активності з урахуванням іiі мовленнєпороджувальних механізмів; б) структурування корекційного впливу на основі врахування інформації, отриманої під час психолінгводіагностики й спостереження за дитиною; в) створення адекватно організованого середовища для здійснення корекційного впливу (структурування режиму, часу, простору, створення розвивального мовленнєвомовного середовища); г) здійснення корекції емоційного стану дитини 3 метою формування мотивації до засвоєння нового мовленнєвого матеріалу й підвищення мовленнєвої активності; 
г) використання аутостимуляцій як невід’ємної частин поведінки дитини 3 аутистичними порушеннями 3 метою наповнення iї новим інформаційно-пізнавальним сенсом, який стане основою для формування мовленнєвої активності; д) використання відповідної кількості завдань, зміна яких передувала б перенасиченню позитивними емоційними враженнями; е) поетапне пред'явлення завдань 3 обов'язковим використанням цілеспрямованого стимулювання як способу формування мотивації до взаємодії та безпосередньої мовленнєвої активності; є) взаємозв'язок у роботі спеціалістів і батьків дітей 3 аутистичними порушеннями; ж) стимуляція мовленнєвої активності засобами психолінгвістичних завдань $з$ урахуванням механізмів, станів і рівнів розвиненості індивідуальної мови й мовлення та особливостей комунікативномовленнєвої поведінки дитини з аутистичними відхиленнями.

Результати формувального експерименту переконують, що хоча діти старшого дошкільного віку, які мають аутистичні порушення, не досягли високого рівня розвитку мовленнєвої активності, але в експериментальній групі визначилися діти 3 достатнім іiі рівнем, збільшилася кількість дітей 3 середнім рівнем i зменшилася кількість дошкільників 3 нульовим рівнем мовленнєвої активності.

Таким чином, можна зробити мотивований висновок щодо ефективності експериментальної психолінгводидактичної технології як такої, що може бути використана як складова при організації освітньо-виховного процесу старших дошкільників 3 аутистичними порушеннями.

Проведене дослідження не вичерпує всіх аспектів проблеми мовленнєвої активності в дітей 3 порушеннями аутистичного спектру в зв'язку з його складністю та різноманітністю питань, що входять до цієї проблеми. Перспективи подальшого дослідження вбачаємо в розробці психолінгвістичної технології покрокового формування мовленнєвої активності в дітей 3 порушеннями аутистичного спектру органів сприймання, починаючи з середнього дошкільного віку.

\section{Література}

Ахутина Т.В. Порождение речи. Нейролингвистический анализ синтаксиса. Москва: Изд-во МГУ, 1989. 215 с. 
Psychological Linguodidactics of Speech Development Activity...

Базима Н.В. Формування мотивації мовленнєвої активності у дітей з аутистичними порушеннями. Науковий часопис НПУ імені М.П. Драгоманова. 2013. Вип. 19. Т. 23. С. 10-14.

Баенская Е.Р. Помощь в воспитании детей с особым эмоциональным развитием. Младший дошкольный возраст. Альманах ИКП. 2001. № 4. С. 23-25.

Башина В.М. Аутизм в детстве. Москва: Медицина, 1999. 236 с.

Белянин В.П. Психолингвистика. Москва: Флинта, Москов. психолого-социальн. ин-тут, 2009. 420 с.

Богдашина О. Аутизм: определение и диагностика. Донецк: ООО «Лебедь», 1999. $166 \mathrm{c}$.

Визель Т.Г. Основы нейропсихологии. Москва: АСТАстрель Транзиткнига, 2005. $384 \mathrm{c}$.

Жинкин Н.И. Язык. Речь. Творчество. Москва: Лабиринт, 1998. 366 с.

Жинкин Н.И. Психолингвистика: Изб. труды. Москва: Лабиринт, 2009. 288 с.

Зимняя И.А. Педагогическая психология. Москва: «Логос», 2000. 384 с.

Зимняя И.А. Лингвопсихология речевой деятельности. Москва: Московский психол.-соц. ин-т; Воронеж: НПО «МОДЭК», 2001. 432 с.

Калмикова Л.О. Психологія розвитку мовленнєвої діяльності дітей дошкільного віку: дис. ... д-ра психол. наук: 19.00.07. Київ, 2011. 462 с.

Конопляста С.Ю., Косинкіна В.О. До проблеми мовленнєвої активності дітей дошкільного віку 3 аутистичними проявами. Науковий часопис НПУ імені М.П. Драгоманова. 2013. Вип. 24. С. 134-137.

Лебединская К.С., Никольская О.С. Диагностика раннего детского аутизма: начальные проявления. Москва: Просвещение, 1991. 96 с.

Леонтьев А.А. Основы психолингвистики. 4-е изд., испр. Москва: Смысл, 2005. $288 \mathrm{c}$.

Морозова С.С. Аутизм: коррекционная работа при тяжелых и осложненных формах. Москва: ВЛАДОС, 2007. 176 с.

Никольская О.С., Баенская Е.Р., Либинг М.М. Аутичный ребенок. Пути помощи. Москва: Теревинф, 2000. 336 с.

Никольская О.С., Баенская Е.Р., Либлинг М.М., Костин И.А., Веденина М.Ю., Аршатский А.В., Аршатская О.С. Дети и подростки с аутизмом. Психологическое сопровождение. Москва: Теревинф, 2005. 224 с.

Островська К.О. Засади комплексної психолого-педагогічної допомоги дітям 3 аутизмом: монографія. Львів: Тріада плюс, 2012. 520 с.

Рождественська М.В., Конопляста С.Ю. Ранній дитячий аутизм. Київ: НПУ ім. М.П. Драгоманова, 2004. 69 с.

Скрипник Т.В. Феноменологія аутизму: монограф. Київ: «Фенікс», 2010. 368 с.

Тарасун В.В. Аутологія: монографія. Київ: «МП Леся», 2014. 580 с.

Эльконин Д.Б. Развитие устной и письменной речи учащихся. Москва: ИНТОР, 1998. 112 с.

Шульженко Д.І. Основи психологічної корекції аутистичних порушень у дітей: монографія. Київ: Знання, 2009. 385 с.

Шульженко Д.І., Шеремет М.К. Психолінгвістичні основи корекції мовлення дітей зі спектром аутистичних порушень. Логопедія. 2013. № 4. С. 67-93.

Barbosa, P.G., \& Nicoladis, E. (2016). Deverbal compound comprehension in preschool children. Mental Lexicon, 11(1), 94-114. https://doi.org/10.1075/ml.11.1.05bar

Boyle, W., Lindell, A., \& Kidd, E. (2013). Investigating the Role of Verbal Working Memory in Young Children's Sentence Comprehension. Language Learning, 63(2), 211-242. https://doi.org/10.1111/lang.12003 
Choi, Y., \& Mazuka, R. (2003). Young Children's Use of Prosody in Sentence Parsing. Journal of Psycholinguist Research, 32(2), 197-217. https://doi. org/10.1023/A:1022400424874

Foursha-Stevenson, C., Schembri, T., Nicoladis, E., \& Eriksen, C. (2017). The Influence of Child-Directed Speech on word Learning and Comprehension. Journal of Psycholinguistic Research, 46(2), 329-343. https://doi.org/10.1007/ s10936-016-9441-3

Hurewitz, F., Brown-Schmidt, S., Thorpe, K., Gleitman, L., \& Trueswell, J. (2009). One Frog, Two Frog, Red Frog, Blue Frog: Factors Affecting Children's Syntactic Choices in Production and Comprehension. Journal of Psycholinguist Research, 29(6), 597-626. https://doi.org/10.1023/A:1026468209238

\section{References}

Akhutina, T.V. (1989). Porozhdenie rechi: nejrolingvisticheskij analiz sintaksisa [Speech production. Neurolinguistic analysis of syntax]. Moscow: Izd-vo «MGU» [in Russian].

Bazima, N.V. (2013). Formuvannia motyvatsii movlennievoi aktyvnosti u ditei $\mathrm{z}$ autystychnymy porushenniamy [Formation of the motivation of speech activity of children with autistic disorders]. Naukovyi chasopys NPU imeni M.P. Dragomanova - Scientific journal of the National Pedagogical Dragomanov University, 19 (23), 10-14 [in Ukrainian].

Baienskaia, E.R. (2001). Pomoshch v vospitanii detey s osobym emotsionalnym razvitiiem. Mladshyi doshkolnyi vozrast [Assistance in bringing up children with special emotional development. Junior preschool age]. Almanac ICP - Almanac IES, 4, 23-25 [in Russian].

Bashyna, V.M. (1999). Autizm v detstve [Autism in childhood]. Moscow: Medicine [in Russian].

Belianin, V.P. (2009). Psiholingvistika [Psycholinguistics]. Moscow: Flinta [in Russian].

Bogdashyna, O. (1999). Autizm: opredeleniie i diagnostika [Autism: definition and diagnostics]. Donetsk: Lebed [in Russian].

Vizel, T.G. (2005). Osnovy neiropsyhologii [Fundamentals of neuropsychology]. Moscow: ASSTrastrel Transitkniga [in Russian].

Zhynkin, N.I. (1998). Yazyk. Rech. Tvorchestvo [Language. Speech. Creativness]. Moscow: Labirint [in Russian].

Zhynkin, N.I. (2009). Psiholingvistika: Izbrannye trudy [Psycholinguistics: Selected research]. Moscow: Labirint [in Russian].

Zymniaia, I.A. (2000). Pedagogicheskaia psikhologiia [Pedagogical psychology]. Moscow: Logos [in Russian].

Zimniaia, I.A. (2001). Lingvopsihologiya rechevoj deiatelnosti [Linguopsychology of speech activity]. Moscow: Moskovskij psihol.-soc. in-t; Voronezh: NPO «MODEHK» [in Russian].

Kalmykova, L.O. (2011). Psihologiya rozvitku movlennevoyi diialnosti ditei doshkilnoho viku [Psychology of development of speech activity of children of preschool age]. Doctor's thesis. Kyiv [in Ukrainian].

Konopliasta, S.Yu., \& Kosynkina, V.O. (2013). Do problemy movlennievoii aktyvnosti ditei $\mathrm{z}$ autychnymy proiavamy [To the problem of speech activity 
of preschool children with autistic manifestations]. Naukovyi chasopys NPU imeni M.P. Dragomanova - Scientific journal of National Pedagogical Dragomanov University, 24, 134-137 [in Ukrainian].

Lebedinskaia, K.S., \& Nikolskaia, O.S. (1991). Diagnostika ranneho detskoho autizma: nachalnyie proiavleniia [Diagnosis of early childhood autism: initial manifestations]. Moscow: Prosveshcheniie [in Russian].

Leontev, A.A. (2005). Osnovy psiholingvistiki [Fundamentals of psycholinguistics] (4nd. ed.). Moscow: Smysl [in Russian].

Morozova, S.S. (2007). Autizm: korrektsyonnaia rabota pri tiazhelykh i oslozhnennykh formakh [Autism: correctional work in severe and complicated forms]. Moscow: VLADOS [in Russian].

Nikolskaia, O.S., Baenskaya, E.R., \& Libling, M.M. (2000). Autichnyi rebenok. Puti pomoshchi [Child with autism. Ways of support]. Moscow: Terevind [in Russian].

Nikolskaia, O.S., Baenskaya, E.R., Libling, M.M., Kostin, I.A., Vedenina, M.Yu., et al. (2005). Deti i podrostki s autizmom. Psikholohicheskoie soprovozhdenie [Children and teenagers with autism. Psychological support]. Moscow: Terevind [in Russian].

Ostrovska, K.O. (2012). Zasady kompleksnoii psykholoho-pedahohichnoii dopomohy ditiam z autyzmom [Basis of complex psycho-pedagogical help for children with autism]. Lviv: Triada plus [in Ukrainian].

Rozhdestvenska, M.V., \& Konopliasta, S.Yu. (2004). Rannii dytiachyi autyzm [Early Childhood Autism]. Kyiv: NPU im. M.P. Dragomanova [in Ukrainian].

Skrypnyk, T.V. (2010). Fenomenolohiia autyzmu [Phenomenology of autism]. Kyiv: Fenix [in Ukrainian].

Tarasun, V.V. (2014). Autolohiia [Autologiya]. Kyiv: MP Lesya [in Ukrainian].

Elkonin, D.B. (1998). Razvitie ustnoi $i$ pismennoi rechi uchashchihsia [The development of oral and written speech of pupils]. Moscow: INTOR [in Russian].

Shulzhenko, D.I. (2009). Osnovy psykholohichnoii korektsii autychnykh porushen u ditei [Basis of psychological correction of autistic disorders of children]. Kyiv: Znannia [in Ukrainian].

Shulzhenko, D.I., \& Sheremet, M.K. (2013). Psykholohichni osnovy korektsii movlennia ditei zi spektrom autystychnykh porushen [Psychological basis of correction of children with spectrum of autistic disorders]. Lohopediia - Speech therapy, 4, 67-93 [in Ukrainian].

Barbosa, P.G., \& Nicoladis, E. (2016). Deverbal compound comprehension in preschool children. Mental Lexicon, 11(1), 94-114. https://doi.org/10.1075/ml.11.1.05bar

Boyle, W., Lindell, A., \& Kidd, E. (2013). Investigating the Role of Verbal Working Memory in Young Children's Sentence Comprehension. Language Learning, 63(2), 211-242. https://doi.org/10.1111/lang.12003

Choi, Y., \& Mazuka, R. (2003). Young Children's Use of Prosody in Sentence Parsing. Journal of Psycholinguist Research, 32(2), 197-217. https://doi. org/10.1023/A:1022400424874

Foursha-Stevenson, C., Schembri, T., Nicoladis, E., \& Eriksen, C. (2017). The Influence of Child-Directed Speech on word Learning and Comprehension. Journal of Psycholinguistic Research, 46(2), 329-343. https://doi.org/10.1007/ s10936-016-9441-3

Hurewitz, F., Brown-Schmidt, S., Thorpe, K., Gleitman, L., \& Trueswell, J. (2009). One Frog, Two Frog, Red Frog, Blue Frog: Factors Affecting Children's Syntactic Choices in Production and Comprehension. Journal of Psycholinguist Research, 29(6), 597-626. https://doi.org/10.1023/A:1026468209238 


\section{АНОТАЦІЯ}

Діти старшого дошкільного віку з аутистичними проблемами мають переважно низький рівень мовленнєвої активності, тому в статті поставили за мету теоретично обгрунтувати й розробити поетапну корекційно-розвивальну психолінгводидактичну технологію формування мовленнєвої активності дітей старшого дошкільного віку, використовуючи теоретичні (вивчення, аналіз та узагальнення теоретичних та методичних засад дослідження для визначення стану розробленості проблеми й перспективних напрямків ії вивчення) та емпіричні (психолого-педагогічний експеримент з метою вивчення стану та особливостей розвитку мовленнєвої активності дітей старшого дошкільного віку з аутистичними порушеннями) методи дослідження.

Експериментальна психолінгводидактична технологія містила три етапи роботи над проблемою мовленнєвої активності: дослідницькодіагностичний, корекційно-діяльнісний та функціонально-мовленнєвий.

На дослідницько-діагностичному етапі встановлювався й налагоджувався емоційний контакт, а також діагностувався наявний вихідний рівень мовленнєвої активності. Корекційно-діяльнісний етап полягав у формуванні мовленнєвих та комунікативних умінь, розвитку безпосередньо мовленнєвої активності дітей старшого дошкільного віку з аутистичними порушеннями. На функціонально-мовленнєвому етапі передбачалася діагностика й закріплення досягнень дитини відносно мовленнєвої активності, а також уміння користуватися набутими мовленнєвими навичками в процесі комунікації, наповнення процесу спілкування широкими взаємозв'язками з оточенням.

Результати формувального експерименту переконують, що хоча dimu старшого дошкільного віку з аутистичними порушеннями не досягли високого рівня мовленнєвої активності, але в експериментальній групі визначилися діти з достатнім ії рівнем, збільшилася кількість дітей з середнім рівнем і зменшилася кількість дошкільників з нульовим рівнем мовленнєвої активності, що підтверджує ефективність експериментальної психолінгводидактичної корекційної технології.

Ключові слова: психолінгводидактична технологія, аутистичні порушення, старший дошкільний вік, мовленнєва діяльність, мовленнєва активність, корекційно-розвиткова методика.

Супрун Дарья, Федоренко Марина. Психолингводидактика развития речевой активности у детей старшего дошкольного возраста с аутистическими нарушениями

\section{АННОТАЦИЯ}

Дети старшего дошкольного возраста с аутистическими проблемами имеют преимущественно низкий уровень речевой активности, поэтому в статье поставлна цель теоретически обосновать и разработать поэтапную коррекционно-развивающую психолингводидактическую технологию 
Psychological Linguodidactics of Speech Development Activity...

формирования речевой активности детей старшего дошкольного возраста, используя теоретические (изучение, анализ и обобщение теоретических и методических основ исследования для определения состояния разработанности проблемы и перспективных направлений ее изучения) и эмпирические (психолого-педагогический эксперимент с целью изучения состояния и особенностей развития речевой активности детей старшего дошкольного возраста с аутистическими нарушениями) методы исследования.

Экспериментальная психолингводидактическая технология содержала три этапа работы над проблемой речевой активности: исследовательскодиагностический, коррекционно-деятельностный и функционально-речевой.

На исследовательско-диагностическом этапе устанавливался $и$ налаживался эмоциональный контакт, а также диагностировался имеющийся исходный уровень речевой активности. Коррекционно-деятельностный этап заключался в формировании речевых и коммуникативных умений, развитии непосредственно речевой активности детей старшего дошкольного возраста с аутистическими нарушениями. На функциональноречевом этапе предусматривалась диагностика и закрепление достижений ребенка относительно речевой активности, а также умение пользоваться приобретенными речевыми навыками в процессе коммуникации, наполнение процесса общения широкими взаимосвязями с окружением.

Результаты формирующего эксперимента подтвердили, что хотя дети старшего дошкольного возраста с аутистическими нарушениями не достигли высокого уровня речевой активности, но в экспериментальной группе определились дети с достаточным ее уровнем, увеличилось количество детей со средним уровнем и уменьшилось количество дошкольников с нулевым уровнем речевой активности, что подтверждает эффективность экспериментальной психолингводидактической коррекционной технологии.

Ключевые слова: психолингводидактическая технология, аутистические нарушения, старший дошкольный возраст, речевая деятельность, речевая активность, коррекционно-развивающая методика. 